\title{
脳保護剤（フリーラジカル消去剤）エダラボンの研究開発
}

\author{
渡辺俊明, ${ }^{*}, a$ 田中正彦, ${ }^{b}$ 渡邊和俊, ${ }^{c}$ 高松康雄, ${ }^{d}$ 戸部昭広 ${ }^{e}$
}

\section{Research and Development of the Free Radical Scavenger Edaravone as a Neuroprotectant}

\author{
Toshiaki Watanabe, ${ }^{*}, a$ Masahiko TanaKa, ${ }^{b}$ Kazutoshi Watanabe, ${ }^{c}$ \\ Yasuo TAKAMATSU, ${ }^{d}$ and Akihiro TOBE ${ }^{e}$ \\ Mitsubishi Pharma Corporation, Sales \& Marketing Divison, ${ }^{a}$ 2-5-6 Awaji-machi, Chuo-ku, Osaka 541-0047, \\ Research \& Development Division Pharmaceuticals Development Unit, b 2-2-6 Nihonbashi-Honcho, Chuo-ku, \\ Tokyo 103-8405, Research \& Development Division Pharmaceuticals Development Unit, ${ }^{c} 1000$ Kamoshida- \\ cho, Aoba-ku, Yokohama 227-0033, Research \& Development Division Pharmaceuticals Research \\ Unit, ${ }^{d} 1-1-1$ Kazusa-kamatari, Kisarazu 292-0818 and Strategic Planning Division, ${ }^{e} 2-6-9$ \\ Hirano-cho, Chuo-ku, Osaka 541-0046, Japan
}

(Received December 9, 2003)

\begin{abstract}
Increasing data suggest that oxygen free radical species play detrimental roles in ischemic diseases. A free radical scavenger capable of inhibiting oxidative injury is expected to become a new drug for the treatment of ischemic diseases such as cerebral ischemia. Edaravon (3-methyl-1-phenyl-2-pyrazolin-5-one), which has been developed as an neuroprotective agent for more than 15 years since its discovery, is approved for the treatment of acute cerebral infarction. In this paper, the pharmacologic characteristics and clinical effects of edaravone are reviewed. In early stage of investigation, edaravone was found to have promising activities as an antioxidative radical scavenger, quenching hydroxyl radical $(\cdot \mathrm{OH})$ and inhibiting both $\cdot \mathrm{OH}$-dependent and $\cdot \mathrm{OH}$-independent lipid peroxidation. Edaravone showed inhibitory effects on both water-soluble and lipid-soluble peroxyl radical-induced peroxidation systems, which are different from the inhibitory effects of vitamins $\mathrm{C}$ and $\mathrm{E}$ in each system, respectively. Oxidative injury to cultured endothelial cells caused by arachidonate (AA) peroxides is prevented in the existence of edaravone. To clarify the characteristics of this free radical scavenger, further investigation was carried out. Edaravone ameliorated exacerbation of cortical edema induced by a focal ischemia-reperfusion model in rats, suggesting inhibitory effects on oxidative injury to the blood-brain barrier (BBB). Additionally, edaravone also prevented rat cortical edema caused by intracortical AA infusion in which free radical production and subsequent oxidative injury to the BBB are involved. With advances in in vivo measurement technology of oxygen radicals, edaravone was shown to inhibit postischemic increases in $\cdot \mathrm{OH}$ production and tissue injury in the penumbral or recirculated area in rat cerebral ischemia models. In clinical studies, edaravone improved the core neurologic deficits, activities of daily living, and functional outcome of stroke patients. Furthermore, a study using proton magnetic resonance spectroscopic techniques showed that edaravone preserved $N$-acetyl-aspartate in stroke patients, a promising neuronal marker in the brain. Further investigation is essential for a better understanding of free radical-mediated cerebral injury during ischemia followed by recirculation. We hope that edaravone represents a promising neuroprotectant for drug therapy in acute cerebral ischemia.
\end{abstract}

Key words — edaravone; free radical scavenger; acute cerebral ischemia; oxidative injury

\section{はじめに}

1978 年に Flamm ら¹)よって, フリーラジカル による生体膜の脂質過酸化障害と虚血性脳損傷の関

a)三菱ウェルファーマ株式会社営業本部医薬マーケテ イング部門, b) 同創薬本部開発部門, ${ }^{c)}$ 同創薬本部研究 部門, d) 同創薬本部研究部門, e) 同戦略本部

e-mail: watanabe.toshiaki@mm.m-pharma.co.jp

*本総説は, 平成 15 年度日本薬学会創薬科学賞の受賞 を記念して記述したものである.
連性が初めて提唱された。続いて Siesjo22)や Demopoulos $^{3)}$ は脳虚血におけるフリーラジカルの 有害性を指摘, barbiturate 系の麻酔薬による脳保 護作用の一部にフリーラジカル除去作用が関与して いると考えた。一方, 浅野ら ${ }^{4,5)}$ は, 麻酔作用や脳 代謝抑制作用がないフリーラジカル消去剂がより優 れた脳保護剤になり得ると考えた。 以来, より選択 的な抗酸化作用を示すフリーラジカル消去剤が脳保 
護剤として研究開発の対象となつた。 $\left.{ }^{6}\right)$ フリーラジ カルそのものは短い寿命と高い反応性のために生体 での測定は困難を極めたが，アラキドン酸（AA） 代謝系や一酸化窒素合成酵素などのフリーラジカル 産生系が脳内に実在すること，そしてこれらが脳虚 血あるいは再開通後に活性化しフリーラジカルを産 生し酸化障害が引き起こされることなどが次第に明 らかにされてきた (Fig. 1). ${ }^{7)}$ 特にフリーラジカル は虚血脳において薬物治療領域と言われる ischemic penumbra（ペナンブラ）領域を含む虚血周辺部位 で漸増し, ${ }^{8)}$ そして再開通後に急増する9) ことも証 明されてきた。

フリーラジカル消去剤エダラボン (3-methyl-1phenyl-2-pyrazolin-5-one ; 分子量 174.20, MCI186, ラジカット注 $30 \mathrm{mg}$, Fig. 2) は世界初の脳保 護剤10)として 2001 年 4 月にわが国で承認された。 有害なフリーラジカルを消去無害化して脳を酸化障 害から保護する作用機序を有し，これまでの治療薬 とは全く異なる薬理プロフィールの薬剤である。脳 梗塞急性期に適用され, 脳血栓症のみならず脳塞栓 症にも使用できることから本疾患における治療法の
選択肢が広がることが期待されている，本稿では， エダラボンの発見の経緯と基礎におけるラジカル消 去作用や脳保護作用の特性そして一部臨床成績につ いて概説する.

\section{1. 発見の経緯}

フェノール系化合物が最も強力な酸化力を有する フリーラジカル種であるヒドロキシルラジカル (・OH）を消去することによってプロスタグランジ ン（PGs）代謝活性を促進する11)ことに着目した。 そこで・OH 消去活性の指標として PGs 代謝促進 作用を in vitro 評価系として採用し，ケトーエノー ル互変異性によってフェノール系化合物と化学的に

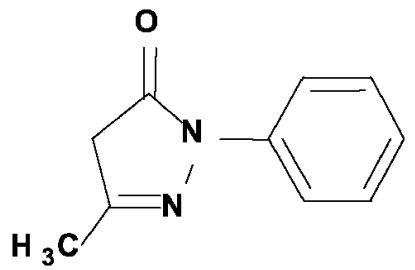

Fig. 2. Chemical Structure of Edaravone (3-methyl-1phenyl-2-pyrazolin-5-one)

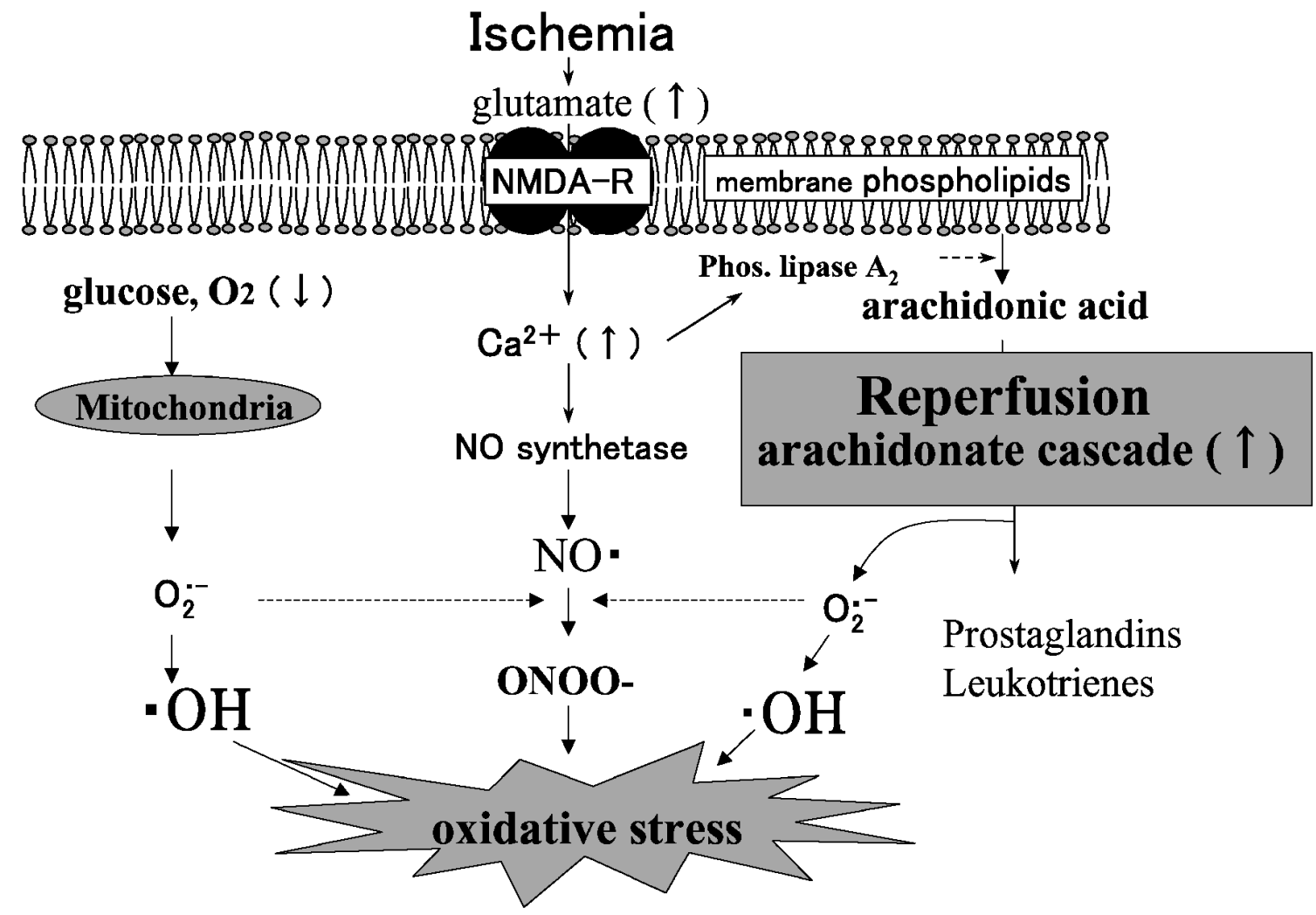

Fig. 1. Major Pathways of Free Radical Production in the Ischemic Brain (from Lewen A. et al., 20007) with modification) 


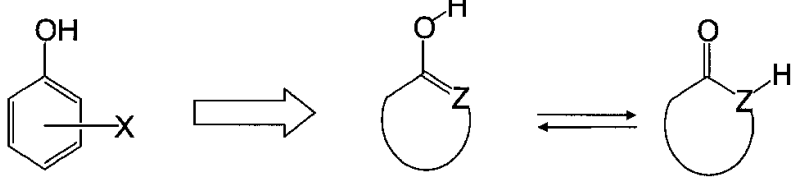

Fig. 3. Design of the Phenol-Like Compounds Generating the Aromatic Hydroxyl Group by Keto-Enol Tautomerization

等価になる（Fig. 3）2-ピラゾリ -5- オン系化合物 を評価したところ，フェノールとほぼ同等の活性を 示す化合物が見出された。 さらに2-ピラゾリ -5オン系化合物についてラット脳ホモジネート自動酸 化 ${ }^{12)}$ に対する酸化抑制作用を検討したところ，多く の化合物で活性が認められた。しかしながら，これ ら化合物の有する PGs 代謝促進活性と脳ホモジ ネート自動酸化抑制活性はかならずしも一致しない ばかりか, 中には一方の評価系でしか活性を示さな い化合物も認められ，さらに・ OH 消去活性を有す るフェノール自身も脳ホモジネート自動酸化に対し てはほとんど効果を示さないことが判明した。これ ら 2 つ in vitro 評価系における評価化合物の活性 の違いについてはいまだ不詳であるが, 脳ホモジ ネートの自動酸化過程では・OH とは異なるフリー ラジカル種が強く関与していることが示唆されてお り，そのため両方の評価系で活性を示す化合物は ・ OH のみならずそれ以外のフリーラジカル種に対 する消去活性も併せ持つことが予測された. ${ }^{13)}$ そこ でこれら 2 つ in vitro 評価系を満たす化合物を選 び，さらにin vivo モデルとして創製したラット全 脳虚血並びに半球脳虚血モデルを用いて，それぞれ 脳波回復作用 ${ }^{13)}$ と抗脳浮腫作用 ${ }^{14)}$ を検討した。これ らの脳虚血モデルでは, 化合物の有効性と同時に中 枢神経系や心循環器系への作用も併せ検討し, より 選択的な脳保護作用を示すエダラボン15)を開発候補 化合物として選択した。

\section{In vitro 薬理作用}

2-1. エダラボンのフリーラジカル消去と抗酸化 作用 ${ }^{15)}$ エダラボンは・OH のみならず酸化力の 強い他のフリーラジカルも消去し, 幅広い抗酸化活 性を有することが示唆されている（Table 1)。すな わち，エダラボンは酸化力をほとんど持たないスー パーオキサイドアニオンラジカル $\left(\mathrm{O}_{2}^{-} \cdot\right)$ には作 用しないが, 強力な酸化力を有する・ $\mathrm{OH}$ を消去
Table 1. Free Radical Scavenging and Antioxidative Actions

\begin{tabular}{|c|c|}
\hline Item & Effects $(\mu \mathrm{M})$ \\
\hline $\left.\mathrm{O}_{2}^{-} \cdot a\right)$ & Negative at $100 \mu \mathrm{M}$ \\
\hline$: \mathrm{OH}^{b)}$ & $\mathrm{IC}_{50}=6.7(3.0-15.3)$ \\
\hline $\begin{array}{l}\cdot \text { OH-induced peroxidation } \\
\text { of linoleic acid }{ }^{c}\end{array}$ & $\mathrm{IC}_{25}=33.8(26.0-44.1)$ \\
\hline $\begin{array}{l}\text { Peroxidation of rat brain } \\
\text { homogenates }^{d)}\end{array}$ & $\mathrm{IC}_{50}=15.3(7.9-29.9)$ \\
\hline $\begin{array}{l}\text { LOO } \cdot \text {-induced lipid } \\
\text { peroxidation }{ }^{e}\end{array}$ & Inhibition \\
\hline $\begin{array}{l}\text { ONOO-induced tyrosine } \\
\text { nitration }^{f)}\end{array}$ & Inhibition \\
\hline \multicolumn{2}{|c|}{$\begin{array}{l}\mathrm{IC}_{25}, \mathrm{IC}_{50} \text { : Inhibition potency calculated by the linear regression } \\
\text { method. }(\mu \mathrm{M}): 95 \% \text { confidential interval. } a \text { ) Superoxide was produced by } \\
\text { xanthine-xanthine oxidase reaction and measured by the increases in } \\
\left.\mathrm{OD}_{515} . b\right) \text { Hydroxyl radical production was initiated by Fenton reaction } \\
\left(\mathrm{H}_{2} \mathrm{O}_{2}+\mathrm{Fe}^{2+}\right) \text { and detected by HPLC as hydroxylated salicylates. } \\
\text { c) Peroxidation initiated by } \cdot \mathrm{OH} \text { was monitored by the increase in } \mathrm{OD}_{234} \cdot \text {. } \\
d \text { d) Autooxidation of the rat brain homogenates was induced by } 30 \text { min in- } \\
\left.\text { cubation at } 37^{\circ} \mathrm{C} \text {. } e \text { ) Described in Fig. } 4 \text {. } f\right) \text { Nitration of tyrosine was } \\
\text { caused by linsidomine }(\mathrm{SIN}-1) \cdot \mathrm{O}_{2}^{-} \cdot: \text { superoxide, } \cdot \mathrm{OH} \text { : hydroxyl radical, } \\
\mathrm{LOO} \cdot: \text { peroxyl radical, ONOO-: peroxynitrite. }\end{array}$} \\
\hline
\end{tabular}

し, また・OH による不飽和脂肪酸の過酸化並び に・OH 非依存性であるラット脳ホモジネートの自 動酸化もそれぞれ抑制した。 エダラボンは脂質ペル オキシルラジカル $(\mathrm{LOO} \cdot)$ による人工リン脂質リ ポソーム膜の過酸化並びにペルオキシナイトライト $\left(\mathrm{ONOO}^{-}\right)$によるチロシンのニトロ化もそれぞれ 抑制した。特に, LOO・による人工リン脂質リポ ソーム膜の過酸化反応に対するエダラボンの抑制活 性は水溶性あるいは脂溶性いずれの系でもほぼ同じ であり，この特性はそれぞれの過酸化反応において 選択的な抑制作用を示す vitamine $\mathrm{C}$ や vitamine $\mathrm{E}$ とは明らかに異なるものであった（Fig. 4). ${ }^{16)}$ 脳虚 血時あるいは再開通後に $\mathrm{O}_{2}^{-}$・がミトコンドリアや $\mathrm{AA}$ 代謝系から産生され, さらに $\mathrm{O}_{2}^{-} ・$ は $\mathrm{Fe}^{2+}$ の 存在下に強力な酸化力を有する・ $\mathrm{OH}$ に変換され る.また $\mathrm{O}_{2}^{-}$・は, 一酸化窒素と反応し, 酸化力の 強い $\mathrm{ONOO}^{-}$に変換され, この $\mathrm{ONOO}^{-}$からは ・ $\mathrm{OH}$ も生成する. これらのフリーラジカルが不飽 和脂肪酸から水素原子を引き抜いて脂質ラジカル $(\mathrm{L} \cdot)$ を生成することにより脂質過酸化反応は開始

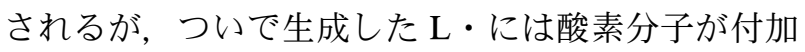
して $\mathrm{LOO}$ ・となり, さらに $\mathrm{LOO} \cdot$ が他の不飽和脂 肪酸から水素原子を引き抜くことによって新たに $\mathrm{L}$ ・を生成させる結果, この脂質過酸化反応は連鎖 的に進行する (Fig. 5). ${ }^{17)}$ エダラボンは・OHのみ ならず LOO・などのフリーラジカルも消去するこ 

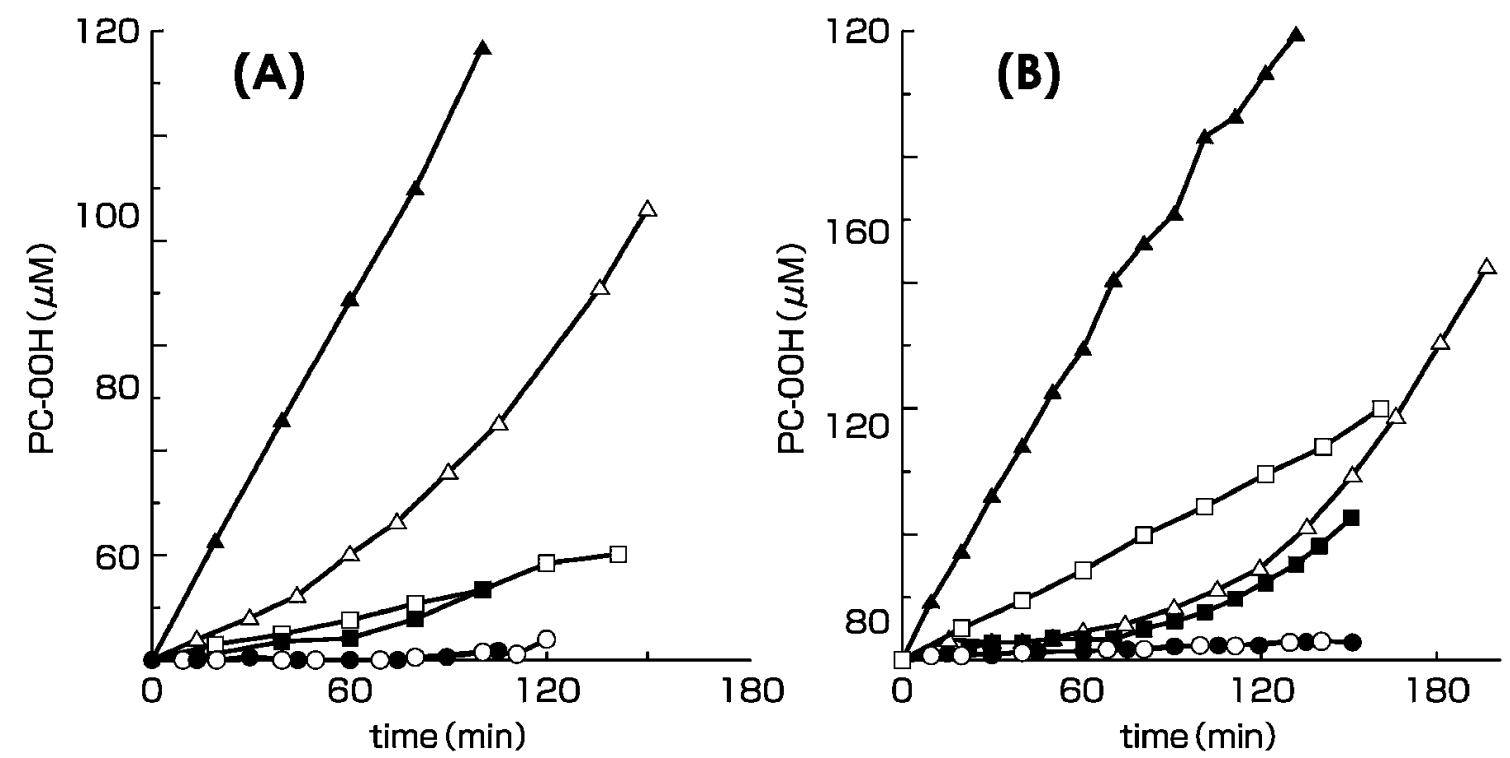

Fig. 4. Effects on Lipid Peroxidation Induced by Peroxyl Radicals

$\boldsymbol{\Delta}$ : Control, $\mathbf{\square}$ : Edaravone $(50 \mu \mathrm{M}), \square$ : Vitamin C $(100 \mu \mathrm{M}), \triangle$ : Vitamin E $(2 \mu \mathrm{M}), \bigcirc:$ Edaravone $(50 \mu \mathrm{M})+$ Vitamin C $(100 \mu \mathrm{M})$, @: Edaravone $(50 \mu \mathrm{M})+$ Vitamin E $(2 \mu \mathrm{M})$. Formation of PC-OOH caused by water-soluble (A) or lipid-soluble (B) peroxyl radicals was detected by increases in OD 234 . PC-OOH: phosphatidylcholine hydroperoxide.

$\mathrm{O} 2$
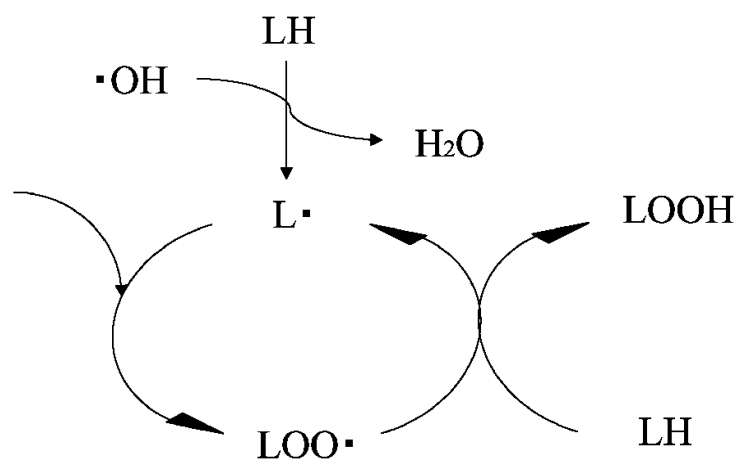

Fig. 5. Initiation and Prolongation of Lipid Peroxidation

LH: polyunsaturated fatty acid, $\mathrm{L} \cdot:$ alkyl radical, $\mathrm{LOO} \cdot:$ peroxyl radical, $\mathrm{LOOH}$ : peroxide. Details are described in the text.

とから，脂質過酸化反応に対してはその開始から連 鎖反応における複数の点で抑制作用を示すと推定で きる.また興味深いことに, エダラボンの脂質過酸 化抑制活性は脂溶性あるいは水溶性いずれの環境下 でも減弱することはなく，このことから本薬剤は vitamine C 並びに E の両方の性質を有するフリー ラジカル消去剤とも言える.

2-2. 内皮細胞の酸化障害抑制作用内皮細胞 がフリーラジカル攻撃に対して脆弱であることは既 に予想されており, ${ }^{11}$ 事実アラキドン酸の過酸化物 である 15-hydroperoxyeicosatetraenoic acid (HPETE) $30 \mu \mathrm{M}$ をウシ大動脈由来血管内皮細胞の培養液中に

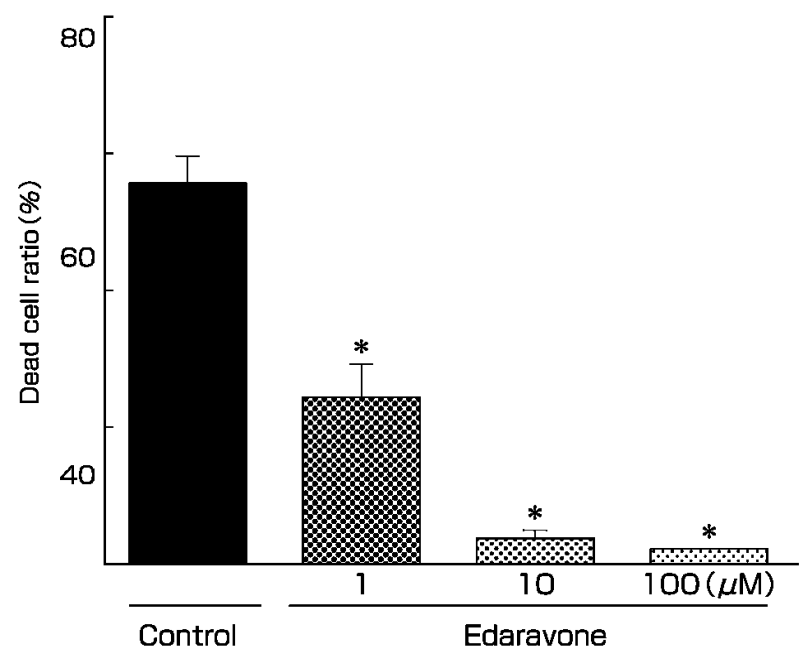

Fig. 6. Effects on Cultured Vascular Endothelial Cell Injury Induced by 15 -HPETE (Mean \pm S.E., $n=3$ )

$*: p<0.05$ vs. control (Dunn's multiple comparison test). Cell damages were caused by $2 \mathrm{hr}$ incubation of cultured cells at $37^{\circ} \mathrm{C}$ in the medium containing 15-HPETE. Dead cells were stained by erythrosine-B. HPETE: hydroperoxyeicosatetraenoic acid.

添加すると強い毒性を示すが, 興味深いことにエダ ラボンは $1 \mu \mathrm{M}$ からこの障害を抑制した（Fig. 6). ${ }^{18)}$ このような強い細胞障害性を引き起こす HPETE は脳虚血再開通によって活性化する AA 代謝系の 中間代謝物であり，15-hydroxyeicosatetraenoic acid (HETE) に変換される過程でフリーラジカル

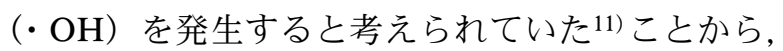


エダラボンはこの HPETE による酸化障害から内 皮細胞を保護したと推測した。その後の研究で HETE には HPETE のような細胞障害性がないこ と，そしてエダラボンと同様にフェノール誘導体も 15-HPETEによる細胞障害を抑制することが判 り, ${ }^{19)}$ この事実はエダラボンが細胞の酸化障害を抑 制し得るとの考え ${ }^{18)}$ を強く支持するものであつた.

\section{2-3. フリーラジカル消去機構 エダラボンの} フリーラジカル消去機構については, LOO ・を始 めとする種々のフリーラジカルとの反応生成物の経 時変化及び反応生成物の同定を行うことにより Fig. 7 のように推定されている. ${ }^{20,21)}$ すなわち，エダラ ボンは生理的条件下では約 50\%がアニオンとして 存在し，このエダラボンアニオンが電子を供与して 種々のラジカルを消去する，その際に生じるエダラ ボンラジカルは反応系中の酸素分子と反応してエダ
ラボンペルオキシルラジカルに変化し，最終的にフ リーラジカルとは無関係な反応生成物である 2-oxo-3-(phenylhydrazono)-butanoic acid (OPB) になる. 密度汎関数法を用いた分子科学計算では, これらエダラボン由来ラジカル種は・OHや LOO・などと較べて著しく反応性が低いことを示 す結果が得られている. ${ }^{22)}$ 以上，エダラボンのフ リーラジカル消去機構としては, エダラボン自らが フリーラジカルと結合する捕捉型ではなくフリーラ ジカルに電子を供与する電子供与型であり, 電子供 与後において生成するエダラボン由来ラジカル種は 酸化力を持たず, 最終的に OPB になるものと推定 している.

\section{In vivo 薬理試験}

3-1. 抗脳浮腫作用エダラボンの抗脳浮腫作 用については, 虚血中はもとより酸化障害が主因と

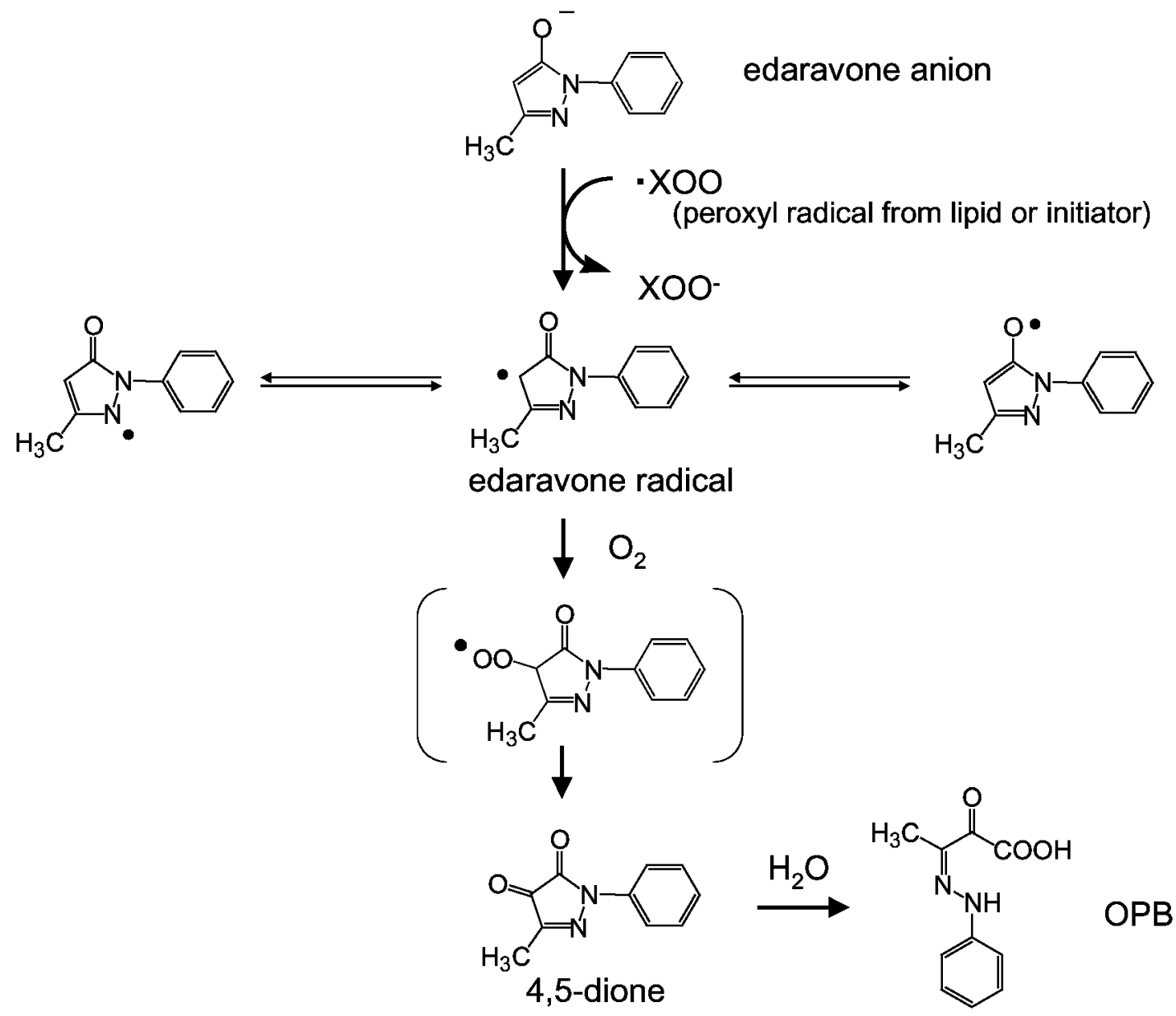

Fig. 7. A Hypothetical Reaction Mechanism of Edaravone with Free Radicals

Electron donation from edaravone to free radicals yields peroxyl anion and edaravone radical, which is transformed into 4,5-dione. Details are described in the text. The hydrolysis of 4,5-dione gives OPB. - XOO: free radicals, XOO-: peroxyl anion, 4,5-dione: 3-methyl-1-phenyl-2-pyrazolin-4,5-dione, OPB: 2-oxo-3(phenylhydrazono)-butanoic acid. 
考えられる虚血再開通に伴う浮腫の増悪を防止する 特性が示唆されている。 すなわち，ラット中大脳動 脈閉塞再開通モデルにおいて，エダラボン $3 \mathrm{mg} /$ $\mathrm{kg}, i . v$.の虚血直後投与は虚血時間（3 hr あるいは $6 \mathrm{hr}$ ）に伴う脳浮腫の進展をそれぞれ抑制し，さら にエダラボン同用量の再開通後投与は再開通 $(3 \mathrm{hr}$ 虚血 $+3 \mathrm{hr}$ 再開通）に伴う脳浮腫の増悪も抑制した (Fig. 8). ${ }^{23)}$ また, 脳虚血再開通後に増加するフ リーラジカルの主な発生源の 1 つが AA 代謝系で あること18)から，AA をラット脳内注入後にエダラ ボン $(0.1-3 \mathrm{mg} / \mathrm{kg}, i . v$. $)$ 投与の効果を検討すると, 本薬剂によって AA 注入 $24 \mathrm{hr}$ 後における脳浮腫は 明らかに抑制された (Fig. 9). ${ }^{24)}$

虚血性脳浮腫は cytotoxic edema と vasogenic edema に大別されており, 虚血再開通によって増悪す るのは，主に血液脳関門（BBB）の障害による透 過性六進が主因となる vasogenic edema である. 25) Kuroiwa ら ${ }^{26)}$ は, ネコ中大脳動脈閉塞再開通モデル において, $3 \mathrm{hr}$ 虚血後 $3 \mathrm{hr}$ 再開通によって脳浮腫 が悪化し, 同時にアルブミンが脳血管外へ著しく漏 洩することを認めている. BBB 機能を司るのは脳 微小血管であるが, その主な構成要素である内皮細 胞は前述の HPETE による内皮細胞障害でも示さ
れたようにフリーラジカルに対して脆弱であること から，同様に BBB 機能自身もフリーラジカルによ る攻撃を受け易いと考えられる。 エダラボンが有効 であった AA 脳内注入による脳浮腫モデルでも AA 注入部位においてフリーラジカルの増加と vasogenic type の脳浮腫の進展が認められている. ${ }^{27)}$

以上，エダラボンは脳虚血とりわけ再開通部位に おいて AA 代謝系活性化などにより増加するフ リーラジカルの攻撃から BBB を構築する内皮細胞 を守ることで, BBB 透過性六進を防ぎ脳浮腫悪化 を防止すると考えられる。臨床上, 心原性脳塞栓患 者では自然再開通が起こり易く，そのためにvasogenic edema の悪化による容態の急変は現在も大き な問題となっている. ${ }^{28)}$ エダラボンにはその薬効の 1 つとして，時に重篤な転帰を招きかねない脳浮腫 の悪化を抑制することが期待されている. ${ }^{29)}$

\section{3-2. 脳神経細胞保護作用 エダラボンの虚血} 脳における主たるターゲット部位としてペナンブラ 領域が想定される。このペナンブラ領域は, 部位的 には血液がほとんど途絶され数分内に energy failure により神経細胞内 $\mathrm{Ca}^{2+}$ 濃度が上昇し直ちに 不可逆的壊死に陥る虚血中心部と正常脳部位の中間 （虚血周辺部）に存在し，その局所平均血流量

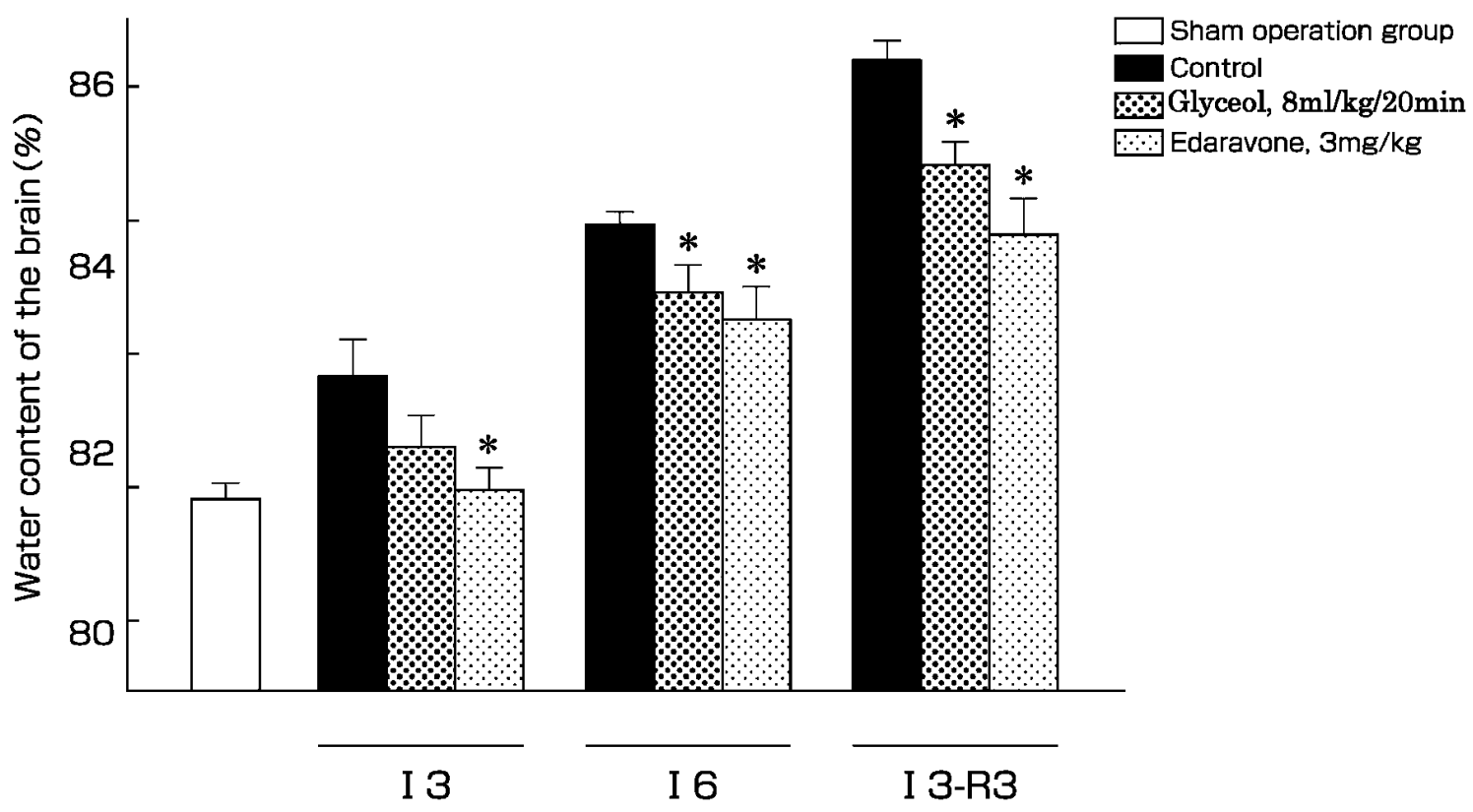

Fig. 8. Effects on Brain Edema in the Rat MCA Occlusion or Occlusion-Recirculation Model (Mean \pm S.D., $n=5$ )

*: $p<0.05$ vs. control (by Dunn's multiple comparison test). The rat MCA occlusion or recirculation was obtained by insertion or removal of nylon thread, respectively. MCA: middle cerebral artery. I3, I6 and I3-R3 refer to "3-hour infarction," "6-hour infarction" and "3-hour infarction-3-hour recirculation," respectively. 


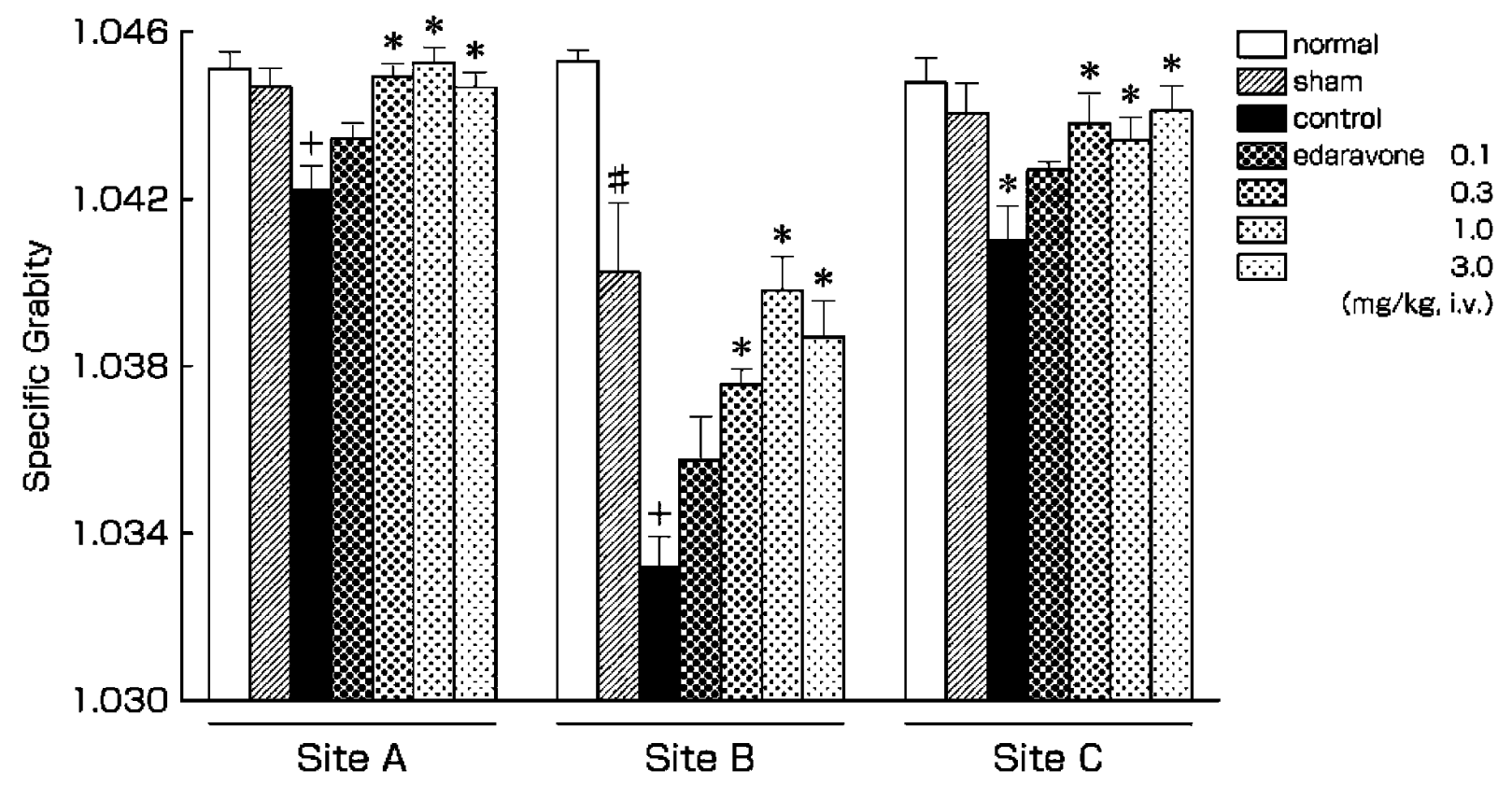

Fig. 9. Effects on Arachidonate-Induced Cortical Edema in Rats (Mean \pm S.E., $n=6-8$ )

Edaravone was i.v. injected after intracortical AA microinjection $(80 \mu \mathrm{g} / \mu \mathrm{l} / 10 \mathrm{~min})$.

$+,{ }^{*},{ }^{*}: p<0.05$ vs. control, sham and normal, respectively (by Dunn's multiple comparison test). Specific gravity of the cortical block was measured $24 \mathrm{hr}$ after AA infusion. AA: arachidonic acid, Site B: AA infusion area, Site A and C: adjacent areas to site B.

（lCBF）は少なくとも $15-30 \mathrm{ml} / 100 \mathrm{~g} / \mathrm{min}$ 程度維 持されている. ${ }^{30)}$ それゆえ, ペナンブラ領域は虚血 中心部とは違って梗塞に至るまで時間的猶予があ り，早期薬物治療あるいは再開通療法によって救済 可能と考えられている.これまで脳梗塞患者の急性 期脳画像においても, ペナンブラ領域は MRI 拡散 強調画像 (diffusion-weighted imaging) で描写され る病巣と MRI 灌流画像 (perfusion imaging) で描 写される低灌流域の間のミスマッチ領域として理解 されている. ${ }^{31)}$ ラット中大脳動脈内血栓モデルにお けるエダラボンの効果を検討したところ, 本薬剤 3 $\mathrm{mg} / \mathrm{kg}, \quad i . v$.の虚血後投与は，大脳皮質部位の虚血 $24 \mathrm{hr}$ 後での梗塞を抑制し, 反対側前後肢の麻痺を 軽減した（Fig. 10). ${ }^{32)}$ Mizuno ら ${ }^{33)}$ は同種モデルの 大脳皮質の虚血周辺部では虚血早期から・OH が増 加すること, そしてエダラボン $3 \mathrm{mg} / \mathrm{kg}, i . v$.の虚 血後投与はこの・OH の増加を抑制し, さらに 24 hr 後の梗塞も減少させることを認めた（Figs. 11, 12).このように虚血周辺部において増加するフ リーラジカルがペナンブラ領域の主たる障害因子の 1 つであるとするならば, ${ }^{8)}$ エダラボンはフリーラ ジカルを消去し脳虚血後の時間経過とともに減少し ていくペナンブラ領域を延命あるいは救済し得るも

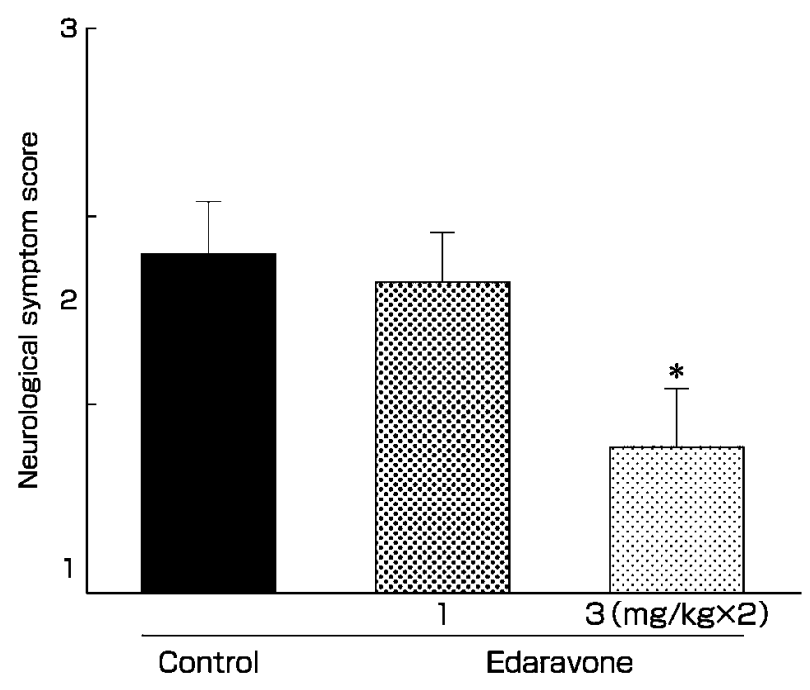

Fig. 10. Effects on Neurological Symptoms in the Rat MCA Thrombosis Model (Mean \pm S.E., $n=10$ )

$*: p<0.05$ vs. control (nonparametric Dunnett's multiple comparison test). The rat thrombosis model was prepared by rose bengal (i.v.) treatment and direct photoirradiation with green light to the left MCA after occlusion of the ipsilateral common carotid artery. Neurological scoring of each rat was carried out $24 \mathrm{hr}$ after thrombus formation as follows;

0 : No symptom. 1: The right fore-leg is placed onto the chest and the left fore-leg is straightened. 2: In addition to the score 1 symptom, resistance is not observed when pushed the left flank. 3: In addition to the score 2 symptom, the body is twisted at the waist. 


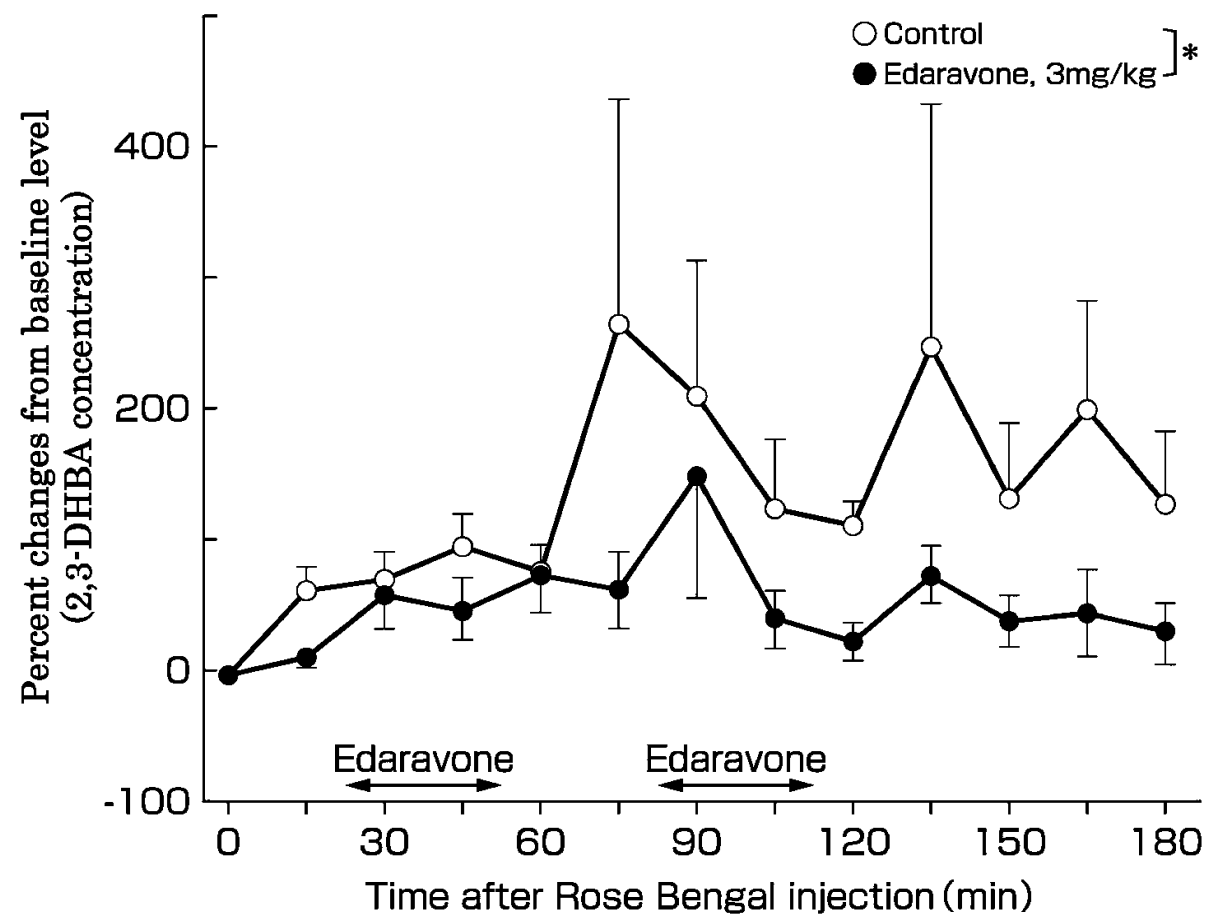

Fig. 11. Effects on Changes of $\cdot \mathrm{OH}$ Production in the Ischemic Penumbra of the Rat Thrombosis Model (Mean \pm S.E., $n=5$ )

$*: p<0.05$ vs. control (analysis of variance (ANOVA)). 2,3-DHBA in the efflux of SA microdialysis was measured by HPLC as an indicator of $\cdot \mathrm{OH}$ formation in the ischemic penumbra. The rat thrombosis model was prepared as described in Fig. 10. Edaravone $(3 \mathrm{mg} / \mathrm{kg} / 30 \mathrm{~min} i . v$. infusion) was treated at 20 and 80 min after occlusive preparation, respectively. 2,3-DHBA: 2,3-dihydroxybenzoic acid, SA: sodium salicylate.

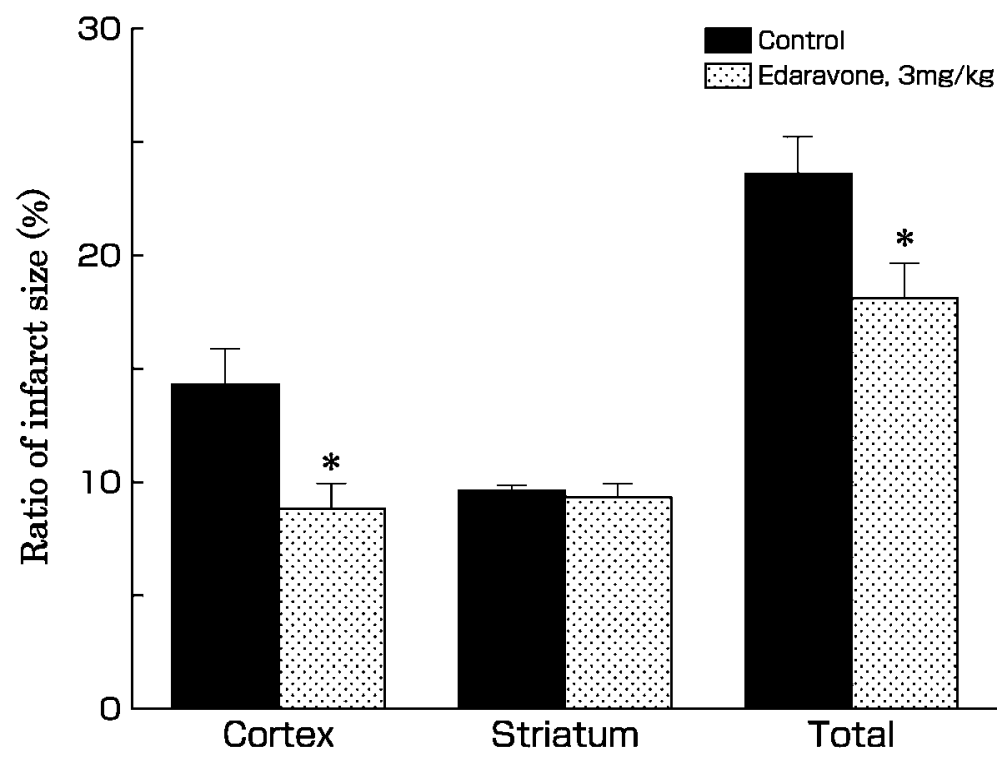

Fig. 12. Ratio of Infarct Size in the Rat MCA Thrombosis Model (Mean \pm S.D., $n=7$ )

*: $p<0.05$ vs. control (Student's $t$-test ). Brain slices were prepared $24 \mathrm{hr}$ after the MCA occlusion and stained with 2,3,5-triphenyltetrazolium. The ratio of infarct size was calculated as \% of the corresponding cerebrum with a computerized image analysis system.

\section{のと考える.}

最近ペナンブラの辺縁部において, 虚血後数日間 に亘る細胞死とそれに伴う梗塞領域の拡大が観察さ れている. ${ }^{34,35)}$ このような遷延性の梗塞拡大には初
期の虚血又は再開通後の酸化ストレスによって活性 化される好中球やミクログリア，アストロサイトな どのいわゆる炎症性細胞群による 2 次酸化障害が密 接に関与すると予想されている. ${ }^{36,37)}$ ラット中大脳 


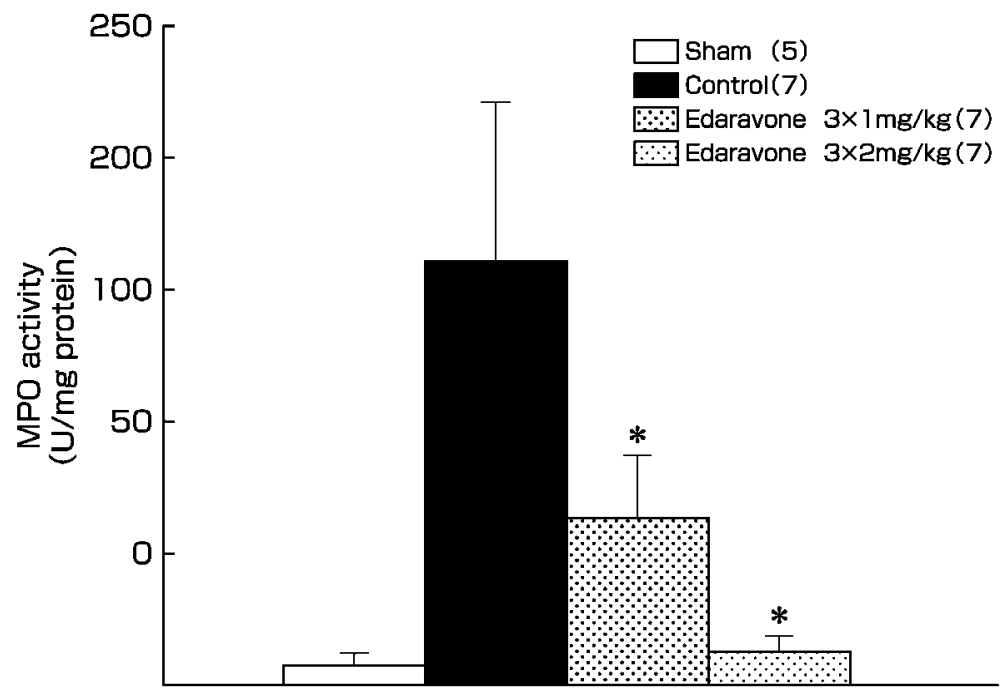

Fig. 13. Effects on Neutrophile Activation in the Rat MCA Occlusion and Recirculation Model (Mean \pm S.E.)

*: $p<0.05$ vs. control group. MPO activity of neutrophiles in the cortex of the occluded side was measured $24 \mathrm{hr}$ after $1.5 \mathrm{hr}$ of MCA occlusion followed by recirculation. 1st and $2 \mathrm{nd} i . v$. injection of edaravone $(3 \mathrm{mg} / \mathrm{kg})$ was carried out immediately and $0.5 \mathrm{hr}$ after recirculation, respectively. MPO: myeroperoxidase, ( ) : number of animals.

動脈閉塞再開通モデルにおいて，エダラボン $3 \mathrm{mg} /$ $\mathrm{kg}, i . v$. の再開通後 1 又は 2 回投与は, 再開通 $24 \mathrm{hr}$ 後に認められる再開通部位での好中球活性化（ミエ ロパーオキシダーゼ活性上昇）を抑制した（Fig. 13)。炎症性細胞が惹起する酸化的障害に対するエ ダラボンの効果については, 今後さらに検討してい $<$.

ペナンブラ領域での神経細胞が速やかな血流再開 によって救済可能であるのに対し, 虚血脳部位によ つては再開通後に血流や脳エネルギーがほぼ正常に 復したにもかかわらず，その後徐々に死滅する細胞 群の存在も以前から知られている. ${ }^{38)} こ の$ 種の細胞 死は虚血あるいは再開通早期に増加するフリーラジ カルによってあらかじめプログラムされてお り, ${ }^{39,40)}$ その代表的なものとして一過性脳虚血後に 海馬領域で生じる錐体細胞の遅発性細胞死が挙げら れる。エダラボン $3 \mathrm{mg} / \mathrm{kg}$, i.v. はラット前脳 10 $\min$ 虚血再開通後投与で海馬領域での・OH の増加 を抑制し, さらに $72 \mathrm{hr}$ 後での遅発性細胞死も抑制 した (Fig. 14, Table 2). ${ }^{41)}$

以上，脳虚血あるいは再開通によって引き起こさ れる様々な有害イベントに対してエダラボンの保護 効果が示されているが，これらはすべて本薬剤のフ リーラジカル消去作用に基づくものと現時点では考 えている. なお近年では, 神経細胞死についてはい わゆるネクローシス/アポトーシスに関する分子的
機序検討が進み, 神経変性疾患におけるフリーラジ カルの重要性が明らかになってきている. ${ }^{42,43)}$ 今後 さらに各種神経変性疾患モデルでエダラボンの有効 性を検討することも意義深いと考える.

\section{4. エダラボンの薬物動態}

エダラボンのラット並びにイヌにおける体内動態 を検討した.いずれの動物種においてもその消失は 速やかで, 主代謝物は硫酸抱合体及びグルクロン酸 抱合体であり，主排泄経路は尿中排泄であっ た. ${ }^{44,45)}$ 第 1 相試験ではエダラボンの投与量と Cmax, AUC はそれぞれ比例関係を示し, 消失半減 期，尿中排泄率は投与量に関係なくほぼ一定であっ た. ${ }^{46)}$ 健常成人並びに健常高齢者におけるエダラボ ン反復投与時で蓄積性は認められず，さらにいずれ の場合も主排泄経路は尿中排泄であり, 主代謝物は グルクロン酸抱合体及び硫酸抱合体であった. ${ }^{47)} ま$ たイヌにおいてエダラボンは血液中から脳脊䯣液中 へ速やかに移行したことから，本薬剤は血液脳関門 を比較的通過し易いと考えられる. ${ }^{48)}$

\section{5. 臨床試験}

適正用量の検討を目的に, 本剂を 1 回 $10 \mathrm{mg}, 30$ $\mathrm{mg}$ 及び $45 \mathrm{mg}$ を 1 日 2 回 14 日間投与する後期第 2 相試験が二重盲検法により行われた。主とした選択 解析 (Protocol Compatible Analysis) 対象 318 例に おける結果から, 適正用量は 1 回 $30 \mathrm{mg}$ であり, 標的症状は神経症候, 日常生活動作障害であると判 


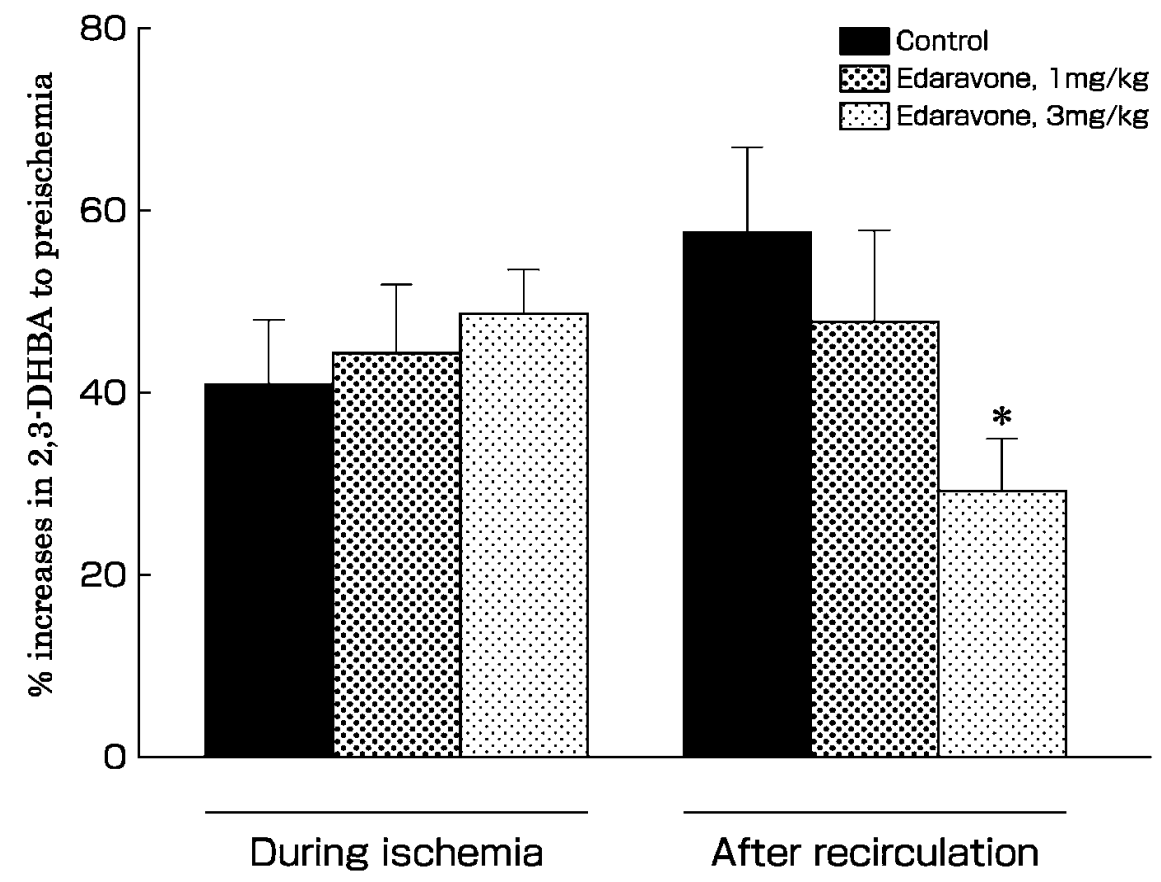

Fig. 14. Effects on Increase in $\cdot \mathrm{OH}$ after Recirculation in the Rat Temporal Forebrain Ischemia Model (Mean \pm S.E., $n=6$ )

*: $p<0.05$ vs. control (Dunnett's multiple comparison test). Hydroxyl radical formation in the hippocampal area was measured by the SA microdialysis technique described in Fig. 11. The \% increases in DHBA during ischemia or after recirculation to preischemic level were calculated. Edaravone (1 and $3 \mathrm{mg} / \mathrm{kg}$, i.v.) was treated immediately after recirculation following to $10 \mathrm{~min}$ of 4 -vessel occlusion.

Table 2. Cytoprotective Effects on Neuronal Cells of the Hippocampal CA1 Area in the Rat Temporal Forebrain Ischemia Model (Mean \pm S.E.)

\begin{tabular}{lccc}
\hline \hline Group & $\begin{array}{c}\text { Dose } \\
(\mathrm{mg} / \mathrm{kg}, i . v .)\end{array}$ & $\begin{array}{c}\text { Number } \\
\text { fo animals }\end{array}$ & $\begin{array}{c}\text { Number of } \\
\text { live cells } \\
(\text { cells } / \mathrm{mm})\end{array}$ \\
\hline Sham & & 7 & $164 \pm 12^{*}$ \\
Control & 1 & 7 & $46 \pm 20$ \\
Edaravone & 3 & 8 & $77 \pm 17$ \\
& 8 & $117 \pm 25^{*}$ \\
\hline
\end{tabular}

$*: p<0.05$ vs. control (Dunnett's comparison test). Survivals of pyramidal cells in the hippocampal CA1 subfield were counted $72 \mathrm{hr}$ after $10 \mathrm{~min}$ of 4-vessel occlusion followed by recirculation.

断した. ${ }^{49)}$

第 3 相試験として，エダラボン 1 回 $30 \mathrm{mg} 1$ 日 2 回 30 分点滴静注の 14 日間投与での有効性, 安全性 を検証する目的で，プラセボ群を対照とした二重盲 検群間比較試験を実施した。対象は発症後 72 時間 以内の脳梗塞 (脳血栓症, 脳塞栓症) 患者で意識障 害が 0-30 (Japan coma scale), 今回の発作に基づ く神経症候, 日常生活動作障害を有する例とした。 主とした包括解析（Intent-to-Treat Analysis）対象 は薬物群，プラセボ群それぞれ 125 例で計 250 例で
あった. 最終観察時における神経症候の改善以上の 率は薬物群 $55 \%$, プラセボ群 $33 \%$, 日常生活動作 障害では薬物群 $50 \%$ ，プラセボ群 34\%であり，標 的症状において改善率の差の $95 \%$ 信頼区間は 0 を またがなかった。最終全般改善度の改善以上の率は 薬物群 $65 \%$ ，プラセボ群 32\%（改善率の差 33\%, 95\%信頼区間：20-45\%）であり，この内，発症後 24 時間以内に投与を開始した患者においては, 改 善率の差は $48 \%$ であった（Table 3)。投与開始 3 力 月以内の退院日（入院中の場合 3 力月後）にModified Rankin Scaleにより評価した機能予後において 群間に順位和検定で有意な差がみられた（Table 4)。副作用は薬物群 9/125 例, プラセボ群 14/125 例に認められたが発現率に差はなく, 薬物群の副作 用は肝機能障害，発疹が主であったがいずれも可逆 的であった. ${ }^{50)}$

以上，エダラボンは適正用量である 1 回 $30 \mathrm{mg} 1$ 日 2 回 30 分点滴静注の 14 日間投与で, 脳梗塞急性 期の中核症状である神経症候, 日常生活動作障害及 び機能予後を改善した。

\section{6. 臨床薬理試験51)}

発症後 24 時間以内で意識障害が Japan coma 
scale で 0-30 のラクナを除く脳梗塞患者を対象と した。第 $1 ， 7$ 及び 28 病日に，関心領域を梗塞巣内 に設定し, 水素磁気共鳴スペクトロスコピー ${ }^{1} \mathrm{H}-$ MRS）を用いて，N-アセチルアスパラギン酸 （NAA），コリンなどを定量した。特にNAA は脳 組織に由来するニューロン特異的なアミノ酸であ り, 脳梗塞発症直後より減少し，24 時間以降の障

Table 3. Final Global Improvement Rating at 1 Month in Acute Brain Infarction

\begin{tabular}{lll}
\hline \hline & \multicolumn{1}{c}{ Edaravone } & \multicolumn{1}{c}{ Placebo } \\
\hline Within 72 hours after onset & $65 \%(n=125)$ & $32 \%(n=125)$ \\
Within 24 hours after onset & $74 \%(n=42)$ & $26 \%(n=39)$ \\
\hline
\end{tabular}

( ) : number of patients.

Table 4. The Modified Rankin Scale Assessed at Discharge within 3 Months or at 3 Months after Onset

\begin{tabular}{cccccccccc}
\hline \hline Grade & 0 & 1 & 2 & 3 & 4 & 5 & Death \\
\hline Edaravone $(n=125)$ & 27 & 36 & 29 & 12 & 10 & 7 & 4 & $p=0.0382^{*}$ \\
Placebo $\quad(n=125)$ & 12 & 35 & 40 & 12 & 15 & 6 & 5 & \\
\hline$*: p<0.05$ vs. placebo (Wilcoxon's rank sum test). ( $):$ number of \\
patients. The outcome was assessed as follows; Grade 0: No symptoms at \\
all, 1: No significant disability despite symptoms, 2: Slight disability, \\
3: Moderate disability, 4: Moderately severe disability, 5: Severe disability.
\end{tabular}

害組織ではほとんど観察されなくなるとされてい る.内部標準としてコリンを用い，第 1 病日のコリ ンに対するNAA の比を求めたところ，NAA は control 群では発症後の時間経過とともに減少し第 28 病日においてはほとんど消失するのに対し, エ ダラボン投与群では第 28 病日でも発症直後の約半 分が残存していた (Fig. 15). この事実はエダラボ ンが脳梗塞患者脳において虚血障害から神経細胞を 保護したことを示唆するものである.

\section{7. おわりに}

エダラボンは脳血管や神経細胞の傷害因子である ラジカルを消去無害化する新規メカニズムの脳保護 剂であり，ラジカルによる酸化的攻撃から細胞を保 護し, 各種脳虚血モデルにおいて神経細胞死, 脳梗 塞, 脳浮腫, 神経脱落症状を抑制する。脳梗塞急性 期に伴う神経症候, 日常生活動作障害, 機能障害に 対し, 発症後 24 時間以内に投与開始とする効能・ 効果, 用法・用量により平成 13 年 4 月に製造承認 を得た。承認取得後もエダラボンの有用性について 市販後臨床試験における長期予後試験などで，さら に検証を重ねていく，一方，平成 14 年 10 月に急性 腎不全に関する緊急安全性情報が出され使用上の注 意を改訂したが，今後も市販後の安全性情報につい

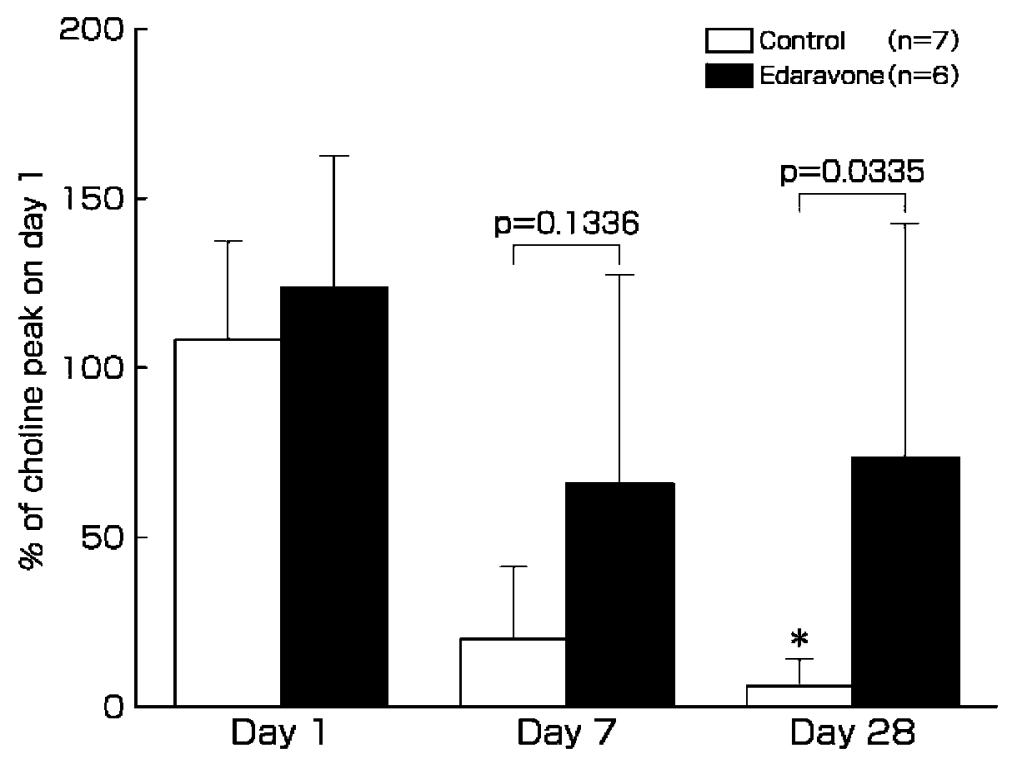

Fig. 15. Sequential Changes of MRS Profile

P-value presented under the remarks represents the result of repeated measures ANOVA as profile analysis (time $\times$ group effect). P-value over the bar-plot (day 7 and day 28 represent the result of ANOCONA using day 1 data for covariance). ( $\square)$ : control $(n=7),(\square)$ : Edaravone $(n=6)$. A: NAA (ratio to day 1 choline). $p=.0359$. After giving their informed consent and in accordance with the regimen used for clinical trials, patients within $24 \mathrm{hr}$ of stroke onset were enrolled. Edaravone was treated for consecutive 2 weeks $(30 \mathrm{mg} /$ body $/ 30 \mathrm{~min} i . v$. infusion $\times 2 /$ day $)$. MRS analysis was carried out on day 1,7 and 28 of postinfarction, respectively; sequential signal changes (creatine, NAA and lactate peaks) in the area of interest were evaluated as ratios to the internal reference (choline peak). MRS: magnetic resonance spectroscopy, NAA: N-acetyl-aspartate. 
て十分な注意を払い，その的確な把握と医療現場へ の速やかな反映に努めるとともに，基礎及び臨床的 検討を継続し, 脳梗塞急性期治療に末永く貢献した いと考えている.

さらに近年，多くの疾患でフリーラジカルの関与 が指摘されており，これまでも腩虚血以外の様々な モデル動物においてエダラボンの有用性が示唆され ている. 今後エダラボンが脳梗塞以外の疾患でも役 立つよう, 研究開発を進めていく所存である.

\section{REFERENCES}

1) Flamm E. S., Demopoulos H. B., Seligman M. L., Poser R. G., Ransohoff J., Stroke, 9, 445-447 (1978).

2) Siesjo B., J. Cereb. Blood Flow Metab., 1, 155 -185 (1981).

3) Demopoulos H. B., Flamm E. S., Pietronigro D. D., Seligman M. L., Acta Physiol. Scand., 492, 91-119 (1980).

4) Asano T., Sano K., Neurol Med Chir (Tokyo) , 7, 549-554 (1979).

5) Tamura A., Asano T., Sano K., Tsumagari T., Nakajima A., Stroke, 10, 126-134 (1979).

6) Asanuma M., IGAKU NO AYUMI, 177-181 (2001).

7) Lewen A., Marz P., Chan P. H., J. Neurotrauma, 17, 879-890 (2000).

8) Morimoto T., Globus M. Y., Busto R., Martinez E., Ginsberg M. D., J. Cereb. Blood Flow Metab., 16, 92-99 (1996).

9) Peter O., Back T., Lindauer U., Busch C., Megow D., Dreier J., Dirnagl U., J. Cereb. Blood Flow Metab., 18, 196-205 (1998).

10) The Edaravone Acute Brain Infarction Study Group, Cerebrovasc. Dis., 15, 222-229 (2003).

11) Kuehl F. A. Jr., Humes J. L., Beveridge G. C., Van Arman C. G., Egan R. W., Inflammation, 2, 285-294 (1977).

12) Zaleska M. M., Floyd R. A., Neurochem. Res., 10, 397-410 (1985).

13) Watanabe T., Yuki S., Egawa M., Nishi H., $J$. Pharmacol. Exp. Ther., 268, 1597-1604 (1994).

14) Nishi H., Watanabe T., Sakurai H., Yuki S., Ishibashi A., Stroke, 20, 1236-1240 (1989).

15) Watanabe T., Yuki S., Saito K., Sato S.,
Sugimoto J., Ohori Y., Jpn Pharmacol Ther., 25, 181-187 (1997).

16) Yamamoto Y., Kuwahara T., Watanabe K., Watanabe K., Redox Report, 2, 333-338 (1996).

17) Porter N. A., Caldwell S. E., Mills K. A., Lipids, 30, 277-290 (1995).

18) Watanabe T., Nishi H., Morita I., Murota S., Prostaglandins Leukot. Essent. Fatty Acid, 33, 81-87 (1988).

19) Ochi H., Morita I., Murota S., Biochim. Biophys. Acta, 1136, 247-252 (1992).

20) Watanabe K., Watanabe K., Hayase T., Jpn Pharmacol Ther., 25, 1699-1707 (1997).

21) Watanabe K., Watanabe K., Kuwahara T., Yamamoto Y., J. Jpn. Oil Chem. Soc., 46, 797-801 (1997)

22) Ono S., Okazaki K., Sakurai M., Inoue Y., $J$. Phys. Chem. A., 101, 3769-3775 (1997).

23) Abe K., Yuki S., Kogure K., Stroke, 19, 480485 (1988).

24) Watanabe T., Egawa M., J. Pharmacol. Exp. Ther., 271 (3) , 1624-1629 (1994).

25) Klatzo I., Piraux A., Laskowski E. J., J Neuropathol Exp Neurol., 17, 548-64 (1958).

26) Kuroiwa T., Shibutani M., Okeda R., Acta Neuropathol., 76, 62-70 (1988).

27) Chan P. H., Fishman R. A., Fed. Proc., 43, 210-213 (1984).

28) Otsubo R., THE SAISHIN-IGAKU, 37, 841847 (2003).

29) Toyota K., Okada Y., NOUKOUSOKUKYUSEIKI-TIRYO NO SHINPO Iyaku (Medicine and Drug) Journal Co., Ltd. 129132 (2002).

30) Astrup J., Symon L., Branston N. M., Lassen N. A., Stroke, 8, 51-57 (1977).

31) Beaulieu C., de Crespigny A., Tong D. C., Moseley M. E., Albers G. W., Marks M. P., Ann. Neurol., 46, 568-578 (1999).

32) Kawai H., Nakai H., Suga M., Yuki S., Watanabe T., Saito K. I., J. Pharmacol. Exp. Ther., 281, 921-927 (1997).

33) Mizuno A., Umemura K., Nakashima M., Gen. Pharmacol., 30, 575-578 (1998).

34) Matsui T., Mori T., Tateishi N., Kagamiishi Y., Satoh S., Katsube N., Morikawa E., Morimoto T., Ikuta F., Asano T., J. Cereb. Blood Flow Metab., 22, 711-722, (2002). 
35) Tateishi N., Mori T., Kagamiishi Y., Satoh S., Katsube N., Morikawa E., Morimoto T., Matsui T., Asano T., J. Cereb. Blood Flow Metab., 22, 723-734 (2002).

36) Barone F. C., Feuerstein G. Z., J. Cereb. Blood Flow Metab., 19, 819-834 (1999).

37) Chan P. H., J. Cereb. Blood Flow Metab., 21, 2-14 (2001).

38) Kirino T., Sano K., Acta Neuropathol., 62, 209-218 (1984).

39) Sugita Y., Kondo T., Kanazawa A., Itou T., Mizuno Y., No To Shinkei, 45, 325-331 (1993) .

40) Sorokina E. G., Reutov V. P., Pinelis V. G., Vinskaya N. P., Vergun O. V., Khodorov B. I., Membr. Cell Biol., 13, 389-396 (2000) .

41) Yamamoto T., Yuki S., Watanabe T., Mitsuka M., Saito K.I., Kogure K., Brain Res., 11, 762, 240-242 (1997).

42) Fiskum G., Murphy A. N., Beal M. F., J. Cereb. Blood Flow Metab., 19, 351-369 (1999).

43) Ferri K., Kroemer G., Nature Cell Biol., 3, 255 -263 (2001).
44) Komatsu T., Masaki K., Nakai H., Drug Metab. Pharmacokin., 11, 463-480 (1997).

45) Komatsu T., Masaki K., Nakai H., Drug Metab. Pharmacokin., 11, 499-504 (1997).

46) Shibata H., Arai S., Izawa M., Murasaki M., Takamatsu Y., Izawa O., Takahashi C., Tanaka M., Jpn. J. Clin. Pharmacol. Ther., 29, 863 -876 (1998).

47) Yokota S., Kumagai Y., Uchiumi M., Isawa S., Murasaki M., Akimoto K., Iwamoto M., Yuasa T., Iwano M., Jpn. J. Clin. Pharmacol. Ther., 28, 693-702 (1997).

48) Takamatsu Y., Watanabe T., Jpn. Pharmacol. Ther., 25, 1793-1797 (1997).

49) MCI-186 Acute Cerebral Infarction Study Group, J. Clin. Exp. Med., 185, 841-863 (1998).

50) The Edaravone Acute Brain Infarction Study Group (chair: Otomo E.), Cerebrovasc. Dis., 15, 222-229 (2003).

51) Houkin K., Nakayama N., Kamada K., Noujou T., Abe H., Kashiwaba T., J. Stroke Cerebrovasc. Dis., 7, 1-9 (1998). 